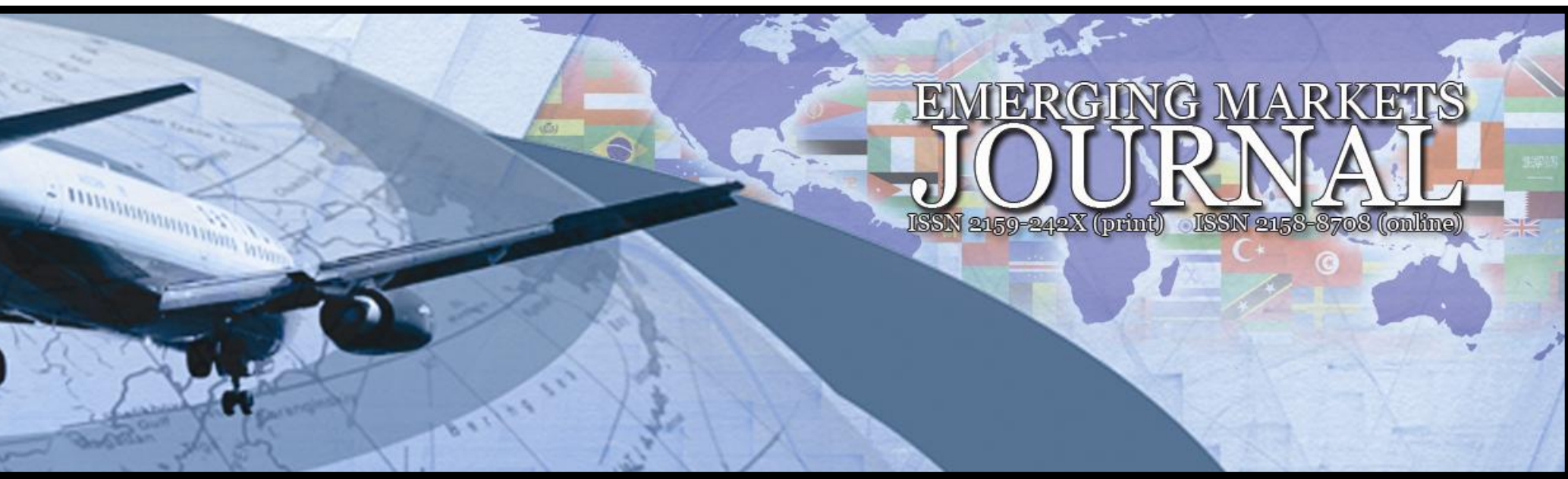

\title{
Intermediate Appellate Review of Commercial Law Decisions In Turkey
}

\section{Dr. Berna Tepe}

Attorney at Law | email: bernatepe@gau.edu.tr

Volume 4 No 1 (2014) | ISSN 2158-8708 (online) | DOI 10.5195/emaj.2014.51 | http://emaj.pitt.edu |

\section{Abstract}

The judiciary in Turkey is still preparing for the expected intermediate appellate review (istinaf) mechanism in Turkey although the official date for its functioning is yet to be specified. Under Turkish law, a first instance court decision can be appealed not because an assertion or a claim is rejected, but due to a substantive or procedural norm of law which should have been applied during the proceedings in an accurate manner. The scope of such review also covers the suitability of the first instance court's decision. There are nonfunctional aspects to the judicial review as specified in the 2011 Code of Civil Procedure of which a major column of novelties consist of the suspended mechanism of dual appellate review. However, the 2011 Code of Civil Procedure regulates the intermediate appellate review as a series of procedural acts and steps. The reasons to appeal a first instance court's decision can rather be deduced from the provisions of 2011 Code of Civil Procedure. In order to structure the reasons and stages of the intermediate appellate review in Turkey, a distinction is made in the present article between (i) review over the appeal's conditions of admissibility, (ii) review of the decision's legality, (iii) review of the decision's legitimacy. Rationally, the reasons for intermediate appellate review should be construed as to accomodate at least the grounds for higher appellate review as well as the extraordinary judiciary review. As different areas of private law are based on different principles, it is noteworthy that cases referred to herein pertain to commercial law. Finally, due to the parallelism between the Turkish and the French legal systems, references to decisions given by the French jurisdiction on commercial matters are made throughout the present article.

Keywords: judicial review, appeal, Turkish law, Code of Procedure, procedural law, court of appeal, appellate review, Commercial Code, joint and several liability, joinder of lawsuits

\section{$(\mathrm{cc}) \mathrm{BY}$}

New articles in this journal are licensed under a Creative Commons Attribution 3.0 United States License.

\section{ULLS D-Song}

This journal is published by the University Library System of the University of Pittsburgh as part

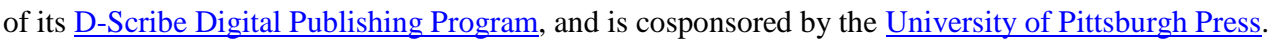




\section{Intermediate Appellate Review Of Commercial Law Decisions In Turkey}

\author{
Dr. Berna Tepe
}

\section{INTRODUCTION}

The dual appellate review has been introduced by the 2011 (revised) Code of Civil Procedure as to replace the ordinary type of reviews currently both conducted by the Court of Cassation. ${ }^{1}$ With the effective establishment of the intermediate appellate review, while the Court of Cassation's organisation is not expected to change in a significant manner, the jurisdiction of each main court of appeal would cover a certain geographical area of Turkey. ${ }^{2}$ Inspired by the current preparations in that vein, the present article is based on the 2011 Code of Civil Procedure's provisions on appeal regulating how intermediate review is to be conceived in Turkey; the appellate column of the code will enter into effect when the courts of appeal start functioning.

The right to judicial review is considered to be important by the actors of the juridical system including the European Court of Human Rights. That being said, an empirical research conducted in 2006 and 2007 revealed that only seventeen percent of the Istanbul district courts' decisions (subject to judicial review) ${ }^{3}$ were in fact appealed before the Court of Cassation; in addition, it

\footnotetext{
${ }^{1}$ The provisions related to judicial review of the 2011 Code of Civil Procedure will enter into effect when the courts of appeal are established. That being said, it has been announced by the Minister of Justice in June 2013 that the courts of appeal will hopefully start to function in 2014 because organisational preparations are reportedly concluded. Anadolu Ajansı, "istinaf Mahkemeleri için Hazırlıklar Tamam" web-based article of 19 June 2013, available at www.aa.com.tr. In 2012, even a regulation concerning rules of expertise to the courts of appeal was issued in 2012. "Bölge Adliye Mahkemesi Adli Yargı Adalet Komisyonlarınca Bilirkişi Listelerinin Düzenlenmesi Hakkında Yönetmelik", Resmi Gazete (Official Gazette) of 8 April 2012, no. 28258.

2 "Bölge Adliye Mahkemelerinin Kurulmasına ilişkin Karar", Resmi Gazete (Official Gazette) of 5 June 2007, no 26543, and see also Act no. 5235 "Adlî Yargı ilk Derece Mahkemeleri ile Bölge Adliye Mahkemelerinin Kuruluş, Görev ve Yetkileri Hakkında Kanun", Resmi Gazete (Official Gazette) of 7 October 2004, no. 25606.

${ }^{3}$ Note of B. Tepe
}

was also evaluated that the judicial review by the Court of Cassation absorbs a significant amount of time. ${ }^{4}$ It is noteworthy that the district courts used to be the primary first instance court before 2011 Commercial Code and the 2011 Code of Civil Procedure entered into effect. Some actors of the juridical system in Turkey are anxious that the disposition periods (between the filing and definite resolution of a case) as a primary indicator of the efficiency of a juridical system would be critically affected once the courts of appeal start functioning. ${ }^{5}$

In Turkey, the reasons to appeal a first instance court's decision can rather be deduced from the provisions of 2011 Code of Civil Procedure. Intermediate appellate review in Turkey is the review of a first instance court's decision by a court of appeal as a judiciary body independent from the first instance court. It is to be initiated by a party having a legitimate interest in appealing. A major step to clarify intermediate appellate review in a structural manner for commercial matters is comparing the two ordinary types of judicial review according the 2011 Code of Civil Procedure, i.e. intermediate appellate review before a court of appeal and higher appellate review before the Court of Cassation:

\footnotetext{
${ }^{4}$ i. Elveriş, G. Jahic, S. Kalem, "Istanbul Asliye Hukuk Mahkemelerinde Yargılama Süreci", İstanbul Bilgi University Publications, 2009, p. 9 ff.

5 For regular reports on the administration of justice in the member States of the Council of Europe including Turkey on - inter alia - data based on the two primary indicators of the efficiency of the juridical systems, see, European Commission for the Efficiency of Justice (CEPEJ) of the Council of Europe, reports entitled "Evaluation Report on European Judicial Systems", Council of Europe, available at www.coe.int .
} 
Table 1: Intermediate Appellate Review and Higher Appellate Review Comparison

\begin{tabular}{|c|c|c|}
\hline & $\begin{array}{c}\text { Intermediate } \\
\text { Appellate Review }\end{array}$ & $\begin{array}{c}\text { Higher Appellate } \\
\text { Review }\end{array}$ \\
\hline $\begin{array}{c}\text { Purpose of } \\
\text { judicial review }\end{array}$ & $\begin{array}{l}\text { Review of the } \\
\text { decisions of the first } \\
\text { instance courts from } \\
\text { factual and legal } \\
\text { standpoints as to } \\
\text { secure accuracy in } \\
\text { judgement and an } \\
\text { accurate application } \\
\text { of the norms and } \\
\text { rules pertaining both } \\
\text { to procedural and } \\
\text { substantive law. }\end{array}$ & $\begin{array}{l}\text { Review of judiciary } \\
\text { decisions as to } \\
\text { secure conformity } \\
\text { with norms of } \\
\text { procedural and } \\
\text { substantive law as } \\
\text { well as to reach an } \\
\text { harmonious } \\
\text { application of law } \\
\text { within Turkey. }\end{array}$ \\
\hline $\begin{array}{l}\text { Timing and } \\
\text { prescribed } \\
\text { period of } \\
\text { appeal }\end{array}$ & $\begin{array}{l}\text { Upon receipt of the } \\
\text { reasoned final } \\
\text { decision of the court } \\
\text { on the subject-matter } \\
\text { and within a period } \\
\text { of two weeks }\end{array}$ & $\begin{array}{l}\text { Upon receipt of the } \\
\text { reasoned final } \\
\text { decision of the court } \\
\text { on the subject- } \\
\text { matter and within a } \\
\text { period of one } \\
\text { month. }\end{array}$ \\
\hline $\begin{array}{l}\text { Concentration } \\
\text { of appeal }\end{array}$ & $\begin{array}{l}\text { If there are various } \\
\text { reasons to take the } \\
\text { decision to the } \\
\text { intermediate } \\
\text { appellate court, they } \\
\text { should be set forth } \\
\text { jointly and upon the } \\
\text { final decision which } \\
\text { terminates the first } \\
\text { instance } \\
\text { proceedings. }\end{array}$ & $\begin{array}{l}\text { If there are various } \\
\text { reasons to take the } \\
\text { decision to the } \\
\text { intermediate } \\
\text { appellate court, they } \\
\text { should be set forth } \\
\text { jointly and upon the } \\
\text { final decision which } \\
\text { terminates the first } \\
\text { instance } \\
\text { proceedings. }\end{array}$ \\
\hline \multirow{3}{*}{$\begin{array}{l}\text { Impact of } \\
\text { appeal }\end{array}$} & $\begin{array}{l}\text { The decision cannot } \\
\text { get definitive. }\end{array}$ & $\begin{array}{l}\text { The decision cannot } \\
\text { get definitive. }\end{array}$ \\
\hline & $\begin{array}{l}\text { Intermediate appeal } \\
\text { per se does not } \\
\text { suspend } \\
\text { implementation of } \\
\text { the decision unless } \\
\text { such suspense is } \\
\text { decided upon deposit } \\
\text { of a caution in } \\
\text { accordance with the } \\
\text { Act on } \\
\text { Implementation and } \\
\text { Bankruptcy. }\end{array}$ & $\begin{array}{l}\text { Higher appeal does } \\
\text { not suspend } \\
\text { implementation of } \\
\text { the decision unless a } \\
\text { caution is deposited } \\
\text { according to the Act } \\
\text { on Implementation } \\
\text { and Bankruptcy. }\end{array}$ \\
\hline & $\begin{array}{l}\text { Intermediate appeal } \\
\text { devolves the } \\
\text { litigation to the court } \\
\text { of appeal either in a } \\
\text { definite manner or } \\
\text { by resumption of } \\
\text { proceedings before a } \\
\text { first instance court, } \\
\text { depending on the } \\
\text { appellate decision. }\end{array}$ & $\begin{array}{l}\text { The litigation is } \\
\text { merely reviewed as } \\
\text { concerns the } \\
\text { applicable norms } \\
\text { and rules of law. }\end{array}$ \\
\hline
\end{tabular}

It is noteworthy that both in Turkey and France, the higher appellate review is characterized by its purpose to reach unity and accurate application of law on a countrywide basis. The higher appellate review by the
French Court of Cassation focuses on the "legal basis" and "rationale" of decisions submitted for review. By institution of intermediate appellate review, the Turkish Court of Cassation should be able to concentrate its review on that primary mission.

It calls for clarification albeit basic that judicial review is initiated not because an assertion or a claim was rejected, but due to a substantive or procedural norm of law which should have been applied during the proceedings in an accurate manner; suitability of the first instance decision to the case is also reviewed.

Intermediate appeal devolves the lawsuit to the court of appeal: (i) the decision is reviewed in terms of suitability and observance of legal norms, (ii) the pleadings as well as the defence and evidentiary items "can" be discussed over before the court of appeal, (iii) unless not in conformity with the specific rules or nature of intermediate appellate review, all procedural acts can be performed during intermediate appellate review.

Reasonably, recourse to review can only be made upon notification of the decision stating the reasons and rationale of the court to a party. Therefore, the prescribed period within which requests for appellate review can be made starts upon receipt of the reasoned decision of a court; for any exception to apply, the exception should have been made explicit in black letter by the legislator. ${ }^{6}$ 


\section{DECISIONS SUBJECT TO INTERMEDIATE Appellate Review}

Table 2. Decisions Subject to Intermediate Appellate Review

\begin{tabular}{|c|c|c|}
\hline $\begin{array}{c}\text { Materiality } \\
\text { criteria }\end{array}$ & $\begin{array}{c}\text { Intermediate } \\
\text { Appellate Review }\end{array}$ & $\begin{array}{c}\text { Higher Appellate } \\
\text { Review }\end{array}$ \\
\hline $\begin{array}{l}\text { Restriction } \\
\text { on types of } \\
\text { decisions }\end{array}$ & $\begin{array}{l}\text { Decisions subject } \\
\text { to appeal are: } \\
\text { (i) final decisions } \\
\text { of a first instance } \\
\text { court (of general or } \\
\text { specific } \\
\text { competence) if not } \\
\text { definitive, issued } \\
\text { through } \\
\text { contentious or } \\
\text { noncontentious } \\
\text { proceedings; } \\
\text { (ii) decisions } \\
\text { rejecting a request } \\
\text { for provisional } \\
\text { measure or } \\
\text { provisional seizure; } \\
\text { (iii) decisions given } \\
\text { upon objection to a } \\
\text { ruling for } \\
\text { injunctive relief or } \\
\text { provisionary secure } \\
\text { seizure to seire } \\
\text { assets }{ }^{7} \text {. }\end{array}$ & $\begin{array}{l}\text { Decisions subject } \\
\text { to higher appellate } \\
\text { review comprise of } \\
\text { : } \\
\text { (i) final decisions } \\
\text { of the courts of } \\
\text { appeal if not } \\
\text { definitive, } \\
\text { excluding the } \\
\text { following: } \\
\text {-decisions } \\
\text { concerning } \\
\text { temporary } \\
\text { protective } \\
\text { measures, } \\
\text { - decisions } \\
\text { concerning } \\
\text { noncontentious } \\
\text { issues, } \\
\text { - ruling of a court } \\
\text { of appeal as } \\
\text { concerns a conflict } \\
\text { of jurisdiction or } \\
\text { competence } \\
\text { between various } \\
\text { first instance } \\
\text { courts, } \\
\text { - ruling to } \\
\text { determine a } \\
\text { competent court } \\
\text { having jurisdiction, } \\
\text { - ruling for } \\
\text { assignment of } \\
\text { another court over } \\
\text { a lawsuit in case of } \\
\text { legal or factual } \\
\text { impediment of a } \\
\text { competent court } \\
\text { with jurisdiction to } \\
\text { hear the dispute; } \\
\text { (ii) decisions given } \\
\text { upon a request for }\end{array}$ \\
\hline
\end{tabular}

7 Decision given upon objection to a ruling for injunctive relief was not considered among "final" decisions which could be appealed (before the Court of Cassation). (Turkish) Court of Cassation, 13. Civil Chamber, decision dated 24 January 1992, no. $10317 / 395$. The same stance has been taken as concerns a decision on an objection to a ruling for provisionary seizure to secure assets. (Turkish) Court of Cassation, 11. Civil Chamber, decision dated 7 October 1991, no. 5057/5179

\begin{tabular}{|c|c|c|}
\hline & & $\begin{array}{l}\text { rescission of an } \\
\text { arbitral award. }\end{array}$ \\
\hline \multirow[t]{3}{*}{$\begin{array}{l}\text { Pecuniary } \\
\text { threshold } \\
\text { for } \\
\text { definiteness } \\
\text { of a } \\
\text { decision } \\
\text { subject to } \\
\text { appeal }\end{array}$} & $\begin{array}{l}\text { For a final decision } \\
\text { not to get definite, } \\
\text { a pecuniary } \\
\text { threshold applies to } \\
\text { decisions } \\
\text { concerning } \\
\text { pecuniary interests. }\end{array}$ & $\begin{array}{l}\text { For a court of } \\
\text { appeal's final } \\
\text { decision not to get } \\
\text { definite, } \\
\text { pecuniary } \\
\text { threshold greater } \\
\text { than the appellate } \\
\text { threshold is } \\
\text { applicable where a } \\
\text { value is attributed } \\
\text { to the dispute. }\end{array}$ \\
\hline & $\begin{array}{l}\text { If the threshold is } \\
\text { relevant, it applies } \\
\text { depending on the } \\
\text { appellant. } \\
\text { concerns a party }{ }^{8} \text {, } \\
\text { the threshold } \\
\text { applies to the value } \\
\text { of the measurable } \\
\text { legitimate interest } \\
\text { he has in appealing } \\
\text { the decision'. As } \\
\text { concerns others, the } \\
\text { threshold is to } \\
\text { apply by reference } \\
\text { to the entirety of } \\
\text { the value that the } \\
\text { cause suggests. }\end{array}$ & $\begin{array}{l}\text { If the threshold is } \\
\text { relevant, it applies } \\
\text { depending on the } \\
\text { applicant. As } \\
\text { concerns the } \\
\text { parties, the } \\
\text { threshold applies } \\
\text { to the value of the } \\
\text { measurable } \\
\text { legitimate interest } \\
\text { he has in applying } \\
\text { against the } \\
\text { decision. For } \\
\text { others, the } \\
\text { threshold is to } \\
\text { apply by reference } \\
\text { to the entirety of } \\
\text { the value that the } \\
\text { cause suggests }\end{array}$ \\
\hline & $\begin{array}{l}\text { (Application of the } \\
\text { pecuniary } \\
\text { threshold to cases } \\
\text { where more than } \\
\text { one person stand as } \\
\text { a party depends on } \\
\text { the severability of a } \\
\text { liability.) }\end{array}$ & $\begin{array}{l}\text { (Application of the } \\
\text { pecuniary } \\
\text { threshold to cases } \\
\text { where more than } \\
\text { one person stand } \\
\text { as a party depends } \\
\text { on the severability } \\
\text { of a liability.) }\end{array}$ \\
\hline
\end{tabular}

\footnotetext{
${ }^{8}$ The term "parties" (for contentious proceedings) is used to cover also interested persons as cocnerns noncontentious proceedings.

${ }^{9}$ In a similar vein, see C. Akil, "istinaf Kavramı", University of Ankara, 2008, PhD thesis available at www.yok.gov.tr, p. 303

${ }^{10}$ This is an interpretation of the intricate provision of the 2011 Code of Civil Procedure, Article 341. Such intricacy could be due to an intention to prevent misuse of strategies by various actors in judiciary actions. This double-sided evaluation could also solve unregulated matters related to the application of the threshold.
} 
The pecuniary threshold for higher appellate review by the Court of Cassation is to apply in the same manner as that applicable to intermediate appellate review. The decision under judicial review of the Turkish Court of Cassation is the "decision of the court of appeal" while the threshold should apply to the value of the legitimate interest a party has in taking the court of appeal's decision to higher appellate review. According to the wording of the 2011 Code of Civil Procedure, Article 314, as concerns third persons, the threshold is to apply by reference to the entirety of the value that the cause suggests.

It is noteworthy that in France, despite the French Court of Cassation's rigorous observance of the rules restricting the possibility to appeal a decision, it is also strongly acknowledged that the law enables appeal as a general principle; when a decision cannot be appealed, such should be based on an explicit wording of the law. ${ }^{11}$ The stated approach makes sense under Turkish law as well.

Finally, due regard should be paid to commercial courts' decisions which are definite by explicit wording in the 2011 Commercial Code although such is critizable because it cannot be said that the practices of the courts are unified at a nationwide basis.

\section{Parties to The Intermediate Appellate Review}

Table 3. Parties to the Intermediate Appellate Review

\begin{tabular}{|c|l|l|}
\hline $\begin{array}{c}\text { Persons who } \\
\text { can appeal }\end{array}$ & $\begin{array}{c}\text { Intermediate } \\
\text { Appellate } \\
\text { Review }\end{array}$ & $\begin{array}{l}\text { Higher Appellate } \\
\text { Review }\end{array}$ \\
\hline $\begin{array}{c}\text { Principal } \\
\text { appeal }\end{array}$ & $\begin{array}{l}\text { Principal appeal } \\
\text { can be lodged by } \\
\text { those who hold a } \\
\text { legitimate in } \\
\text { interest in } \\
\text { appealing the } \\
\text { decision. }\end{array}$ & $\begin{array}{l}\text { Those who hold a } \\
\text { legitimate interest } \\
\text { in applying; others } \\
\text { who may hold a } \\
\text { legitimate interest } \\
\text { in higher appellate } \\
\text { review are not } \\
\text { explicitly stated by } \\
\text { the Code of Civil } \\
\text { Procedure. }\end{array}$ \\
\hline Counterappeal & $\begin{array}{l}\text { Counterappeal is } \\
\text { enabled while } \\
\text { the pecuniary } \\
\text { threshold is not } \\
\text { applicable in } \\
\text { case of is } \\
\text { counterappeal. }\end{array}$ & $\begin{array}{l}\text { Counterappeal is } \\
\text { enabled without } \\
\text { regard to the } \\
\text { pecuniary } \\
\text { threshold. }\end{array}$ \\
\hline
\end{tabular}

${ }^{11}$ See, J. Héron, T. Le Bars "Droit judiciare privé", Montchrestien, 2011, p. 574 et seq.

\begin{tabular}{|l|l|lr|}
\hline Joint appeal & $\begin{array}{l}\text { (Joining the } \\
\text { principal appeal }\end{array}$ & $\begin{array}{l}\text { (Joining the } \\
\text { principal } \\
\text { application is not } \\
\text { is not } \\
\text { specificially } \\
\text { regulated) }\end{array}$ & $\begin{array}{l}\text { specifically } \\
\text { regulated) }\end{array}$ \\
\hline
\end{tabular}

To be able to appeal a first instance court, it is a prerequisite to hold a legitimate interest in appealing. The legitimate "interest" is assessed with reference to the decision given by the first instance court. A declaration of the French Court of Cassation is noteworthy in assessing such "interest" by reference to the date the relevant decision was appealed. Evaluating a subsequent decision for judiciary liquidation against an appelant party, the French Court of Cassation stated that " existence of an interest to appeal a decision is assessed as of the date of appeal and the admissibility of such appeal would not depend on circumstances which occur later". That being said, the French higher appellate court added that "such circumstances could have been depriving the appeal of its subject-matter". ${ }^{12}$ The point evokes the distinction under Turkish law between a condition of action and the subject-matter of the dispute which can be transferred, be conditional on the resolution of another dispute, get out of the control of the defendant, or otherwise change; such distinction is consequential upon the appellate proceedings, also as concerns the division of expenses to be borne by the parties.

Other than the parties to the first instance proceedings, various scenarios exist as concerns the possibility of a third person to hold a legitimate interest in appealing a decision. An indirectly related novelty of the 2011 Code of Civil Procedure is its Article 27 establishing a right to be heard in favor of the parties, those who intervene and any other interested person. The term "interested person" is a term used in various contexts within the 2011 Code of Civil Procedure, viz. collective action in Article 113, minutes of verbal declaration in Article 154, access to the court file in Article 161, noncontentious matters in Article 384, appealing decisions over noncontentious matters in Article 387 and objection to a decision for injunctive reief in Article 394, alinea 3 and 4 of the 2011 Code of Civil Procedure. ${ }^{13}$ If construed in a flexible manner, an interested person is a person who holds a legitimate interest in performing or being involved in the

12 (French) Court of Cassation, 2. Civil Chamber, decision dated 6 April 2006 (04-12.803). (translation by B. Tepe)

${ }^{13}$ Cf. A.C. Budak (2011) "Hukuk Muhakemeleri Kanunu'nun Getirdiği Başlıca Yenilikler", Conference held at Bakırköy Center of the Istanbul Bar Association on 14 May 2011, published by the Istanbul Bar Association: B. Kuru, A.C. Budak, "Hukuk Muhakemeleri Kanunu'nun Getirdiği Başlıca Yenilikler" in Istanbul Barosu Dergisi, Vol. 85 , no.5, 2011, p. 33 f. , available at www.istanbulbarosu.org.tr 
proceedings. However, if construed in a rigid manner, the context of a specific provision should explicitly permit a person holding a legitimate interest to perform or be involved in the relevant procedural act. ${ }^{14}$ At the final analysis, since the relevant provision excludes a person from intervening to the appellate review and permits those who (should) have been involved to the first instance to be involved in the appellate review, whether and to which extent another interested person's right to be heard can be asserted during the appellate review depends on the specific context of the provision underlying his involvement.

The right of appeal of the person who has filed an intervention to the first instance proceedings depends on whether the relevant type of intervention is principal or auxiliary. As concerns the "principal" type of intervention (asli müdahale), since it is asserted that the third party has a right as concerns the subject-matter in dispute and not only a legitimate interest in intervening to the dispute, a certain independency from the parties to the action should be secured as to grant the possibility to appeal independent from the parties. Indeed, grounds of legitimate principal intervention provides an independent area of maneuver during the proceedings. Principal intervention (asli müdahale) entitles the person to appeal the final decision. ${ }^{15}$ Otherwise, with respect to auxiliary intervention (feri müdahale), the (Turkish) Court of Cassation has expressed that, "since the relevant party has not had recourse to the Court of Cassation, a third person who has filed an auxiliary intervention in a party's favor is not entitled to appeal a decision (to the Court of Cassation)“. ${ }^{16}$

If a third person's request for intervention has been rejected by a first instance court, it is acknowledged that such decision can be challenged (before the Court of Cassation) at higher appellate review in an independent manner ${ }^{17}$; the (Turkish) Court of Cassation has declared that rejection of requests for intervention can be appealed both in respect of principal intervention and auxiliary

14 According to the relevant Article 6 of the European Convention of Human Rights to which Turkey is signatory, "(i)n the determination of his civil rights and obligations or of any criminal charge against him, everyone is entitled to a fair and public hearing within a reasonable time by an independent and impartial tribunal established by law."

15 B. Kuru, R. Arslan, E. Yilmaz, "Medeni Usul Hukuk", Yetkin Publication House, 2008, p. 641

${ }^{16}$ (Turkish) Court of Cassation, 12. Civil Chamber, decision dated 11 June 1991, no. 621/7619. (translation by B. Tepe)

${ }^{17}$ (Turkish) Court of Cassation, 11. Civil Chamber, decision dated 29 November 1982, no. 5996/4999. intervention. ${ }^{18}$ The issue is equally important as concerns the timing of an eventual appeal and who would hold a legitimate interest to appeal a court's decision in respect of the request for intervention. Considering that the rejection of an intervention may have "irreversible" effects and that intervention to the appellate review is not permitted $^{19}$, such rejection could be appealed in a seperate manner especially when the significance of principal intervention to a dispute is taken into account. The right to be heard introduced by the 2011 Code of Civil Procedure reinforces such stance as to enable a person to appeal a court decision rejecting his request to intervene to the first instance. As concerns the timing or appeal and the possibility of a party appealing a decision on auxiliary intervention, the practice is noteworthy that the courts avoid declaring an explicit decision especially about auxiliary intervention. The courts should be considering that the decision on intervention can only be reviewed along with the appeal of the final decision resolving the main dispute ${ }^{20}$.

As concerns counterappeal, it is noteworthy that the Court of Cassation first seeks the admissibility of a principal appeal for the admissibility of a counterappeal. $^{21}$

The absence of a specific provision as concerns judgements affecting more than one person is or as concerns dependency between parties is noteworthy; the appeal by one of the parties may influence another especially if he is jointly liable. Similarly, according to the 2011 Commercial Code, Article 7, joint and several liability is presumed for an obligation of commercial nature. On the other hand, according to the 2011 Commercial Code, Article 557 which sets forth a rule of variable (differentiated) joint liability, "(i)n case more than one person is responsible to compensate the same prejudice, each is severally and "jointly" liable for the same prejudice in varying degrees depending on the extent the consequential damage can be imputed on each., ${ }^{, 2}$ The provision sets forth joint and several liability at varying degrees. The plaintiff is entitled to initiate an action holding more than one person liable for the entirety of the claim and request the court to determine the extent of liability for each defendant". ${ }^{23}$ According to the legislative clarifying statement of 2011 Commercial Code, Article 557, the group of persons who are imputed liability for the same prejudice are to be considered as a party in a joint manner. It is further stated that a result of such interpretation, the plaintiff would not need to assume the expenses if the action was rejected in respect

18 (Turkish) Court of Cassation, Civil General Assembly, decision dated 1 April 1987, no. 1987/259

19 Infra, re 2011 Code of Civil Procedure, Article 357

20 See, H. Konuralp, "Medeni Usul Hukuku", Anadolu University, 2006, p.81

${ }^{21}$ (Turkish) Court of Cassation, 2. Civil Chamber, decision dated 27 October 2000, no. 12203/13092.

${ }^{22}$ Translation by $\mathrm{B}$. Tepe

${ }^{23}$ Translation by $\mathrm{B}$. Tepe 
of a number of defendants, but others were still held liable. However, the provision's wording is consequential not only as concerns judiciary expenses, but in order to qualify the type of co-existence between the parties in a more general manner. In general joint action/joint defence (dava arkadaşlığı) is founded and the types vary according to three elements: (i) whether the joint nature is mandatory according to the law or is optional, (ii) the procedural stage at which joinder can be effected, (iii) the type of procedure. The provision does not set forth a strict substantive rule of codependency between defendants. Considering the two main types of joint action, i.e. mandatory joint action and joint action by choice, the mandatory joint action under the first type arises from substantive law. Mandatory joinder by reasons of substantive law requires a connection between grounds of action which appears as a prior relationship between the defendants, generally independent of the dispute; it is enabled in order to prevent incoherence and leads to a strict procedural codependency. Overall, due to potential conflicts of interest, Article 557 cannot be construed as to allow mandatory substantive codependency between such defendants (maddi zorunlu dava arkadaşll $\breve{g}_{l}$ ), but can well require procedural codependency for the facts of the case to be revealed in a complete and accurate manner. Article 557 of the Commercial Code is built on a norm of substantive law, namely "joint liability" for joinder, but suggests a connection rather for procedural reasons and in order to provide means for the facts of the dispute to be revealed in a complete and accurate manner.

If there is a prejudice and if the plaintiff requests that prejudice to be recognized, assessed and compensated for, every person who can be held liable jointly with others even if severally, but in varying degrees, conflicts of interest may arise between defendants; each defendant should be able to act independently throughout the same proceedings for efficiency in attaining justice. Joint action by choice is a type of joinder instituted for reasons of procedural economics. ${ }^{24}$ Taking into account the general principle enabling parties' control under the law of procedure, the Commercial Code, Article 557 can be conducive both to mandatory procedural dependency (usuli zorunlu dava arkadaşlı $\breve{g}$ ) and joint action by choice (ihtiyari dava arkadaşll $\breve{g}_{l}$ ) between defendants. Under both types of joinder, each defendant may still appeal the first instance court's decision in an independent manner. ${ }^{25}$

24 Ö. Ulukapı, Regulation of Co-action under the Law of Civil Procedure", University of Ankara, 1990, Thesis available at www.yok.gov.tr, p. 38 and p. 356

${ }^{25}$ The legislative clarifying statement is even more noteworthy in this respect because it refers to a decision of the German Federal Court where the said high court has reportedly considered its parallel provision under German law to be applicable only during the first instance proceedings.

\section{SCOPE OF INTERMEdiate APPELlate REVIEW}

Table 4. Scope of Intermediate Appellate Review

\begin{tabular}{|c|c|c|}
\hline & $\begin{array}{c}\text { Intermediate } \\
\text { Appellate Review }\end{array}$ & $\begin{array}{c}\text { Higher Appellate } \\
\text { Review }\end{array}$ \\
\hline Scope of review & $\begin{array}{l}\text { - Review as concerns } \\
\text { conformity with } \\
\text { appellate procedure; } \\
\text { - Review as concerns } \\
\text { conformity of } \\
\text { proceedings before } \\
\text { the first instance } \\
\text { court in respect of } \\
\text { the norms and rules } \\
\text { of procedural and } \\
\text { substantive law; } \\
\text { - Review of the } \\
\text { accurate application } \\
\text { of law covering the } \\
\text { suitability of the } \\
\text { decision to the case. }\end{array}$ & $\begin{array}{l}\text { - Review as } \\
\text { concerns } \\
\text { conformity with } \\
\text { higher appellate } \\
\text { procedure; } \\
\text { - Review of the } \\
\text { accuracy in } \\
\text { respect of the the } \\
\text { law or the } \\
\text { agreement } \\
\text { applicable } \\
\text { between } \\
\text { parties to the case; } \\
\text { - Conformity of } \\
\text { proceedings in } \\
\text { respect of the } \\
\text { norms and rules of } \\
\text { procedural and } \\
\text { substantive. }\end{array}$ \\
\hline $\begin{array}{l}\text { Adversariality: } \\
\text { whether the } \\
\text { reasons of appeal } \\
\text { restrict the } \\
\text { judicial review }\end{array}$ & $\begin{array}{l}\text { In principle, the } \\
\text { course of } \\
\text { intermediate } \\
\text { appellate review is } \\
\text { restricted by the } \\
\text { points of appeal that } \\
\text { the appellant party } \\
\text { asserted. However, } \\
\text { the courts of appeal } \\
\text { are empowered to } \\
\text { take into } \\
\text { consideration } \\
\text { concerns of public } \\
\text { order for its review } \\
\text { in case of an obvious } \\
\text { nonobservance. }\end{array}$ & $\begin{array}{l}\text { In principle, } \\
\text { course of higher } \\
\text { appellate review is } \\
\text { restricted by the } \\
\text { reasons asserted } \\
\text { by the appellant } \\
\text { party. However, } \\
\text { the Court of } \\
\text { Cassation is } \\
\text { empowered to take } \\
\text { into consideration } \\
\text { explicit legal } \\
\text { norms for its } \\
\text { review in an } \\
\text { exceptional } \\
\text { manner for } \\
\text { obvious violation } \\
\text { of such. }\end{array}$ \\
\hline $\begin{array}{l}\text { Proscription to } \\
\text { introduce new } \\
\text { assertions, } \\
\text { defence or } \\
\text { evidence }\end{array}$ & $\begin{array}{l}\text { In principle, the } \\
\text { parties can neither } \\
\text { present new } \\
\text { assertions, claims or } \\
\text { defences, nor submit } \\
\text { any new evidentiary } \\
\text { item for intermediate } \\
\text { appeal. Exceptions to } \\
\text { the mentioned } \\
\text { principle are as } \\
\text { follows: } \\
\text { - In case a court of } \\
\text { appeal exceptionally } \\
\text { needs to consider a } \\
\text { point of law in an ex } \\
\text { officio manner, the } \\
\text { judicial review could } \\
\text { be inclusive of a new } \\
\text { claim, defence, } \\
\text { assertion on } \\
\text { evidentiary item; }\end{array}$ & \\
\hline
\end{tabular}




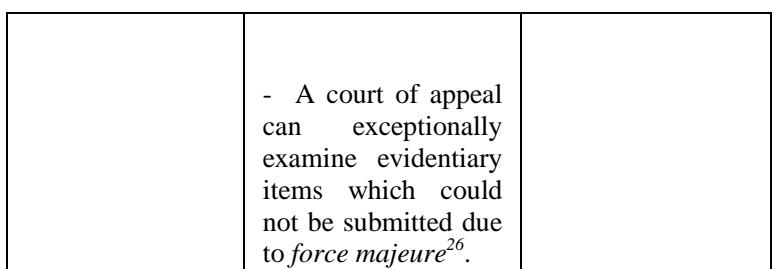

Under Turkish law, it is the decision given by the first instance court which is under review, focusing on whether the decision can be "objectively erroneous" 27. The institution of appeal as a judicial review mechanism under Turkish law is characterized by its narrow scope ${ }^{28}$ as specified by the legislative clarifying statements of the Code of Civil Procedure. ${ }^{29}$ The intermediate appellate review is narrow in its conception in Turkey for various statutory reasons. In principle, it is not permited to present a new assertion, claim, defence or evidence which has not been brought before the court of first instance unless any such needs to be taken into account ex officio by the court of appeal according to the Code of Civil Procedure, Article 357. Moreover, it is also proscribed to lodge a counterclaim, to intervene to the proceedings, or to resume the proceedings which is practically the primary exception to the proscription to expand the assertions or defence according to the Code of Civil Procedure, Article 176 et seq.

Based on the foregoing nonpermissive provisions, the Code of Civil Procedure expects the parties to have drawn a picture representing the dispute as of the date of filing, for the court to make a conciliatory painting to fit to the frame set by the laws while the court of appeal is to check whether its colors are harmonious or if the frame is the one suitable to the final picture. However, law is quite often the result of traditions, of social expectations; legal rules are applied according to national pre-understanding. ${ }^{30}$ Although civil procedural law is characterized by formality, to what extent should

${ }^{26}$ The concept of "force majeure" in the related procedural context should be distinguished from the concept of "force majeure" within the framework of the (Turkish) Code of Obligations. For an evaluation questioning the practicality and suitability of the concept of force majeure within its immediate context, see C. Akil, "Istinaf Kavramı", University of Ankara, 2008, PhD thesis available at www.yok.gov.tr, p. $277 \mathrm{ff}$.

${ }^{27}$ C. Akil, "İstinaf Kavramı", University of Ankara, 2008, PhD thesis available at www.yok.gov.tr, p. $316 \mathrm{ff}$.

${ }^{28}$ Op. cit,. Kuru et al., "Medeni Usul Hukuk", 2008, p. 637

29 Ibidem, p. 639

30 P. Gottwald, "Comparative Civil Procedure" in Ritsumeikan Law Review", 2005/3, No. 22, p.25; translation republished as "Karşılaştırmalı Medeni Usul", in "Prof. Dr. Saim Üstündağ'a Armağan" Adalet Publication House, 2009, p.282. law support it so that formality is not conducive to an artefact? If the formality of procedural law introduces a high level of artificialness with rigidity, such would understate the features of the intermediate appellate review. Two major features distinguish the intermediate appellate review. Firstly, its focus on the "suitability" of the decision reviewed to the case and not just on the accurate application of the norms of applicable law. Secondly and due to the same perspective, principle of adversariality which should be maintained during intermediate appellate review.

\section{Suitability of the Decision}

The intermediate appellate review cannot aim to commence the proceedings over as if replacing the first instance proceedings. ${ }^{31}$ In some countries like France, a tension is being witnessed as to whether the review over the facts should be a evaluation, a reevaluation of the facts of the dispute or simply be restricted to legal reframing of facts when necessary as to preserve the supreme discretion of the first instance court over the filed facts. Therefore, during the interpretation of each precedent and statutory exception permissive of a a new assertion, defence or evidence, the French doctrine also reminds that intermediate appeal is, at the final analysis, is a recourse for "review" of the first instance court's decision. $^{32}$

It is remarked at some of the decisions of the French Court of Cassation that a distinction is made between "evaluation of facts", "evaluation of the evidentiary value and effect of proofs", and the "exposure of an evidentiary item to the consideration of the other party or discussions during the proceedings". The French Court of Cassation perseveres in repeating that the evaluation of facts is an issue within the power of evaluation of the first instance court. ${ }^{33}$ However, the French Court of Cassation also reviews how evidence is weighed; it specified that "if the writing (over a document) was contested by its supposed author (party to the lawsuit), the judge must confirm its authenticity unless he could decide without taking the related document into account". ${ }^{34}$ According to the 2011 (Turkish) Code of Civil Procedure, a court of appeal can exceptionally examine an evidentiary item which has

31 On the legal and financial reasons for proceedings not to be repeated during the intermediate appellate review, see, T. Akkaya, "Medeni Usul Hukukunda Istinafa Başvuru, Istinaf incelemesi ve istinaf Mahkemesinin Verebileceği Kararlar" University of Anadolu (Eskişehir), 2008, PhD thesis available at www.yok.gov.tr , p.60 f.

32 Op. cit., J. Héron, T. Le Bars, "Droit judiciare privé", p. 607 et seq.

33 (French) Court of Cassation, Commercial Chamber, decision dated 13 decembre 2011 (application no. 10-27.799)

34 (French) Court of Cassation, Commercial Chamber, decision dated 28 January 2006, no. 293. (Translation by B. Tepe) 
been omitted by the first instance court. The provision does not evoke the proscription to expand evidence simply because it covers a situation where an evidentiary item has been introduced during the first instance proceedings. However, the limited power of evaluation held by the appellate courts over weighing of evidence is conducive to judging whether an omitted or contested evidentiary item is significant for the decision; such depends on the court of appeal's evaluation of the "suitability" of the legal reframing under review.

It is noteworthy that the French Court of Cassation repeatedly reaffirms its negative stance against evaluating the value and effect of an evidentiary item by rejecting to conduct a "higher" appellate review over a decision from such aspect. A stance as the last stated leaves ample room to a court of appeal's review. Moreover, such autonomous evaluation (appréciation souveraine) of the first instance court does not exclude the exercise of an evaluation by the court of appeal if the first instance court's evaluation could be reframed in a more accurate manner or the first instance court could be led to applying the rules of submission of evidence in an accurate manner. The number of French Court of Cassation's references to the "autonomous" evaluation of the court of appeal are significant. A court of appeal's power to evaluate the evidentiary value of a fact has been recognized in a case where the court of appeal has rejected to deduce ill-intention from an irregularity. ${ }^{35} \mathrm{In}$ another case, the French Court of Cassation recently reevaluated that if the amount of damages awarded in the appellate decision is not founded on concrete evidence, the court of appeal's decision is deprived of a legal basis; the French high court still stated at its same decision that the court of appeal has rightfully exercised its power of evaluation as concerns the confusion which had been consciously created between two trademarks conducive to the commercial problem a party has suffered, and also in respect of the resulting amount of damages albeit relatively modest. ${ }^{36}$ Another recent decision of the French Court of Cassation is noteworthy in that it did not sustain the judgement of a court of appeal which is consequential to having the burden of proof reversed (as burden of proof upon the other party). ${ }^{37}$

\section{Principle of Adversariality}

It calls for evaluation how the principle of adversariality should relate to the statutory proscription to introduce new assertions, defences or evidence to the intermediate appellate review. Such proscription reminds the proscription to expand assertions, defence and

35 (French) Court of Cassation, Commercial Chamber, hearing of 8 October 2013 (application no. 12-23343)

36 French) Court of Cassation, Commercial Chamber, hearing of 24 September 2013 (application no. 12-13250) (Translation by B. Tepe)

37 (French) Court of Cassation, 2. Civil Chamber, hearing of 7 November 2013 (application no. 1225437) evidence. Overall, it is the other party which can evoke the proscription if a party does not observe the requirements of the proscription. Before suggesting any exception to the proscription to expand assertions, defence and evidence can be relevant, there is a number of situations where the mentioned proscription is considered to be irrelevant. ${ }^{38}$ Such a situation which is relevant also to intermediate appellate review may occur upon an expert examination or investigation especially on the spot. Ideally, a fact or a type of damage or loss other than that asserted may be revealed during an examination or an investigation. That being said, the general proscription to expand the assertion or defence motivates the court of first instance to determine the scope of an expert's examination for instance by way of questions notified to the expert(s) or even determine the aim of its own investigation on the spot beforehand.

In addition, the Code of Civil Procedure provides a number of exceptions to the proscription to expand the assertion and defence in a general manner, For cases of which the amount or value of the claim cannot be determined, it is permitted that a party files a figurative minimum claim and later modifies its claim as an exception to the proscription to expand the filed claim. Within the situation covered, the claim could not be determined generally because the plaintiff does not have enough of elements to assess the pecuniary value of a claim; either because"it cannot be expected from the plaintiff to determine the amount or value to be claimed or it is (objectively) impossible to determine such an amount or value". 39 As such, it is rather the claim which is modified in a predictable manner rather than the assertion itself. Secondly, the nature of the exception cannot readily accomodate the case where a pecuniary value cannot be attributed to the result sought, e.g. for termination of a contract or rescission of a decision issued by the general assembly of a company.

In practice, it is rare that the court sets out whether it has rejected a certain assertion or defence because a party has reasserted the proscription to expand claims and defence, or because the court has reframed the facts or evaluated the evidence in a certain manner as to produce the resulting decision. Therefore, for a functional evolution of intermediate appellate review, it is significant to set legitimate standards applicable to the review in black letter, but also to have the standards of procedural law applied in practice during the first instance, primarily in terms of maintaining discussions on assertions, defences and evidentiary items presented by the parties, finally reflecting such and the court's evaluation in minutes. Indeed, the 2011 Code of Civil Procedure imposes on the courts not only to conduct ground work in order to explicitly state the issues contested by a party and the points over which the parties agree, but also to draft elaborate minutes during the proceedings. It is noteworthy that in France, it constitutes

\footnotetext{
38 See, Ç. A. Çelik, "Tazminat ve Alacak Davaları", Bilge Yayınevi, Ankara, 2012, p.173 ff.
}

392011 Code of Civil Procedure, Article 107 (translation by B. Tepe) 
a principal reason underlying the appellant's success if the first instance has failed to allow any assertion, defence or evidentiary item for consideration of the other party in a realistic manner; the French Court of Cassation assertively leads the courts to take an active role for an assertion, defence or evidentiary to be discussed between the parties, especially if it has significance. ${ }^{40}$

Adversariality is sustained when it comes to restraining the intermediate appellate review to reasons declared by the application. To express within a more accurate framing, the principle of adversariality constrains the effect of appeal in devolving the subjectmatter to the court of appeal: tantum devolutum quantum appellatum. $^{41}$

Moreover, the proscription against new assertions, defence or evidence is a distinct and explicit proscription included in the 2011 Code of Civil Procedure, Article 357, para.1 and not by a statutory reference to the proscription against expanding assertions, defence and evidence. Can the provision be indicative as to whether the proscription against new assertions, defence and evidence is to be asserted by the other party or to be authorizing the court of appeal to assert it in an ex officio manner? It is explicitly specified in its legislative clarifying statement that the proscription is to be applied by the court of appeal in an ex officio manner. ${ }^{42}$

Rationally, the court of appeal cannot be more restricted in its review than the Court of Cassation is in the higher appellate review. Therefore, it is noteworthy that according to the 2011 Code of Civil Procedure, Article 367, the Court is not bound by the reasons set forth in the application for review and may take into account issues which are not in conformity with explicit provisions of law. A first distinction is made between explicit provisions of law and, e.g. the terms of a contract. Otherwise, the provision allows certain norms of law to be considered by the Court in an ex officio manner. In addition, any evolution of the dispute with impact on a condition of legality can be set forth during the appellate review without considering whether such is a reason stemming from public order or not. Finally, where the first instance court can depart from the specific request, the suitability of a decision can be challenged by the relevant party by taking the decision to the intermediate appellate review.

40 "The report issued by an expert who was not actually assigned by a court (nonjudiciary expertise report) can have evidentiary value" and " that the court of appeal must take into consideration such an expertise report and evaluate the report once it's been brought into the discussions between the parties although the court cannot base its decision exclusively on such a report": (French) Court of Cassation, Combined Chamber, decision dated 28 September 2012, no.271. (Translation by B. Tepe) ${ }^{41}$ Op. cit. Héron, Le Bars "Droit judiciare privé", 2011, p. 594.

42 Ibidem, p. 953
For instance, according to the 2011 Commercial Code, Article 531, the minority shareholder(s) may file a request to the court for dissolution of the relevant jointstock company by asserting rightful reasons. Pleadings within the framework of the relevant Article 531 of the new Commercial Code could arise from various situations: recurrent abuse by majority shareholder(s), continuous argument between the shareholders as to sabotage eventual achievement of the company's object(s) of activity, systematically violating - inter alia a financial right, a voting right or privilege, the rights to information or the rights of examination. However, the court has discretion to decide for the sale of the plaintiff's stock at its true value valid at a time close to the expected decision date of the court, or to resolve the dispute by any other suitable and acceptable means adequate to the situation rather than dissolving the joint-stock company. Therefore, the court could decide for dissolution or pull the plaintiff shareholder out of the company depending on whether the situation affects the plaintiff or rather obstructs the company from functioning. If the first instance court decides that squeezing the plaintiff shareholder out of the company would retrigger the company's functioning, the plaintiff may well appeal the decision for its suitability to the dispute. Can the plaintiff be expected to have submitted assertions and evidence to the first instance court contrary to probable decisions of the court before the decision? A party with legitimate interest in appealing a decision should be able to bring new assertions/evidence and evidence as to why the decision given by the first instance court is not "suitable" to the case and the other party should be able to oppose the appellant in that vein. The proscription should not apply in such cases. Another adverse possibility arises if the court decides for sale of the shareholder's shares at a value which significantly changes until the date of the decision. Would it be possible to prove such change before the court of appeal without introducing new evidence? In such situations as mentioned above, it cannot be objectively expected from a party to have previously filed complete assertions/defence or evidence to the first instance proceedings in support of the appellate declaration subsequent to the decision.

Finally, the 2011 Code Procedure provides for two exceptions to the application of the principle of adversariality: (i) the court of appeal has to take into consideration concerns of public order for its review in case of an obvious nonobservance, and (ii) a court of appeal can exceptionally examine evidentiary items which could not be submitted to the first instance court due to force majeure. Force majeure is generally defined as an incidence which occurs out of a person's control while the person has no prior or subsequent control over the incidence. ${ }^{43}$ When an occurrence is qualified as force majeure, it is considered to be conducive to nonobservance of a liability. However, proceedings do

\footnotetext{
43 Cf., C. Akil, "İstinaf Kavramı", University of Ankara, 2008, PhD thesis available at www.yok.gov.tr, p. 278 (translation by B. Tepe)
} 
not presume or create a liability in a similar sense. ${ }^{44}$ According to the legislative clarifying statement of the provision, evidence of which the submission was late without any fault imputable to a party can be presented as well. ${ }^{45}$ Rationally, the intermediate appellate review should readily accomodate new evidence for the submission of which a person with legitimate interest can initiate the extraordinary judicial review in accordance with the Code Civil Procedure, Article 374 et seq. Deduced from the referred Article 375, para. 1, alinea (ç), it is possible to submit a new document which was obtained after a first instance court decision for reasons not related to the party who was held liable by the decision.

\section{STRUCTURING INTERMEdite Appellate Review}

Intermediate appellate review can be structured into three stages (i) review on conditions of admissibility of the appeal, (ii) review of legality of the first instance court's decision, and (iii) review of legitimacy of the first instance court's decision. The intermediate appellate is first subjected to a preliminary examination of "admissibility" during which it is examined whether requirements of appellate procedure were met or subsequently complied with:

Table 5. Structuring Intermediate Appellate Review

\begin{tabular}{|c|c|c|}
\hline $\begin{array}{l}\text { Preliminary } \\
\text { Examination }\end{array}$ & $\begin{array}{l}\text { Intermediate } \\
\text { Appellate } \\
\text { Review } \\
\end{array}$ & $\begin{array}{l}\text { Higher } \\
\text { Appellate } \\
\text { Review } \\
\end{array}$ \\
\hline $\begin{array}{c}\text { Conditions for } \\
\text { admissibility of } \\
\text { appeal }\end{array}$ & $\begin{array}{l}\text { All applications } \\
\text { are subject to } \\
\text { conditions of } \\
\text { admissibility to } \\
\text { confirm that: } \\
\text {-the decision } \\
\text { must not be } \\
\text { definitive; } \\
\text {-the appeal must } \\
\text { have been filed } \\
\text { within the } \\
\text { prescribed period; } \\
\text {-the prerequisites } \\
\text { of application for } \\
\text { appeal must have } \\
\text { been met; } \\
\text {-reason(s) or } \\
\text { explanation(s) of } \\
\text { appeal must have } \\
\text { been declared. }\end{array}$ & $\begin{array}{l}\text { All applications } \\
\text { are subject to } \\
\text { conditions of } \\
\text { admissibility: } \\
\text { - the decision } \\
\text { must not be } \\
\text { definitive; } \\
\text { - the appeal must } \\
\text { have been filed } \\
\text { within the } \\
\text { prescribed period; } \\
\text { - the prerequisites } \\
\text { of appeal must } \\
\text { have been met; } \\
\text { - reason(s) or } \\
\text { explanation(s) of } \\
\text { appeal must have } \\
\text { been declared. }\end{array}$ \\
\hline
\end{tabular}

${ }^{44}$ Such a liability can be relevant rather within the context of duties of the representing lawyer vis-àvis his client.

${ }^{45}$ TBMM Tutanak Dergisi (Review of the minutes of the Turkish Parliament's sessions), Dönem 22, 5.

Sayısı, 152, Yasama Yılı 1, p. 11, cited by M. A. Tutumlu, "Medeni Yargılama Hukukunda Delillerin ileri Sürülmesi", 2007, p. 954

\begin{tabular}{|c|l|l|}
\hline $\begin{array}{c}\text { Condition } \\
\text { incumbent on } \\
\text { the first } \\
\text { instance court }\end{array}$ & $\begin{array}{l}\text { The assigned } \\
\text { chamber must be } \\
\text { the right chamber } \\
\text { to conduct the } \\
\text { review. }\end{array}$ & $\begin{array}{l}\text { The assigned } \\
\text { chamber must be } \\
\text { the right chamber } \\
\text { to conduct the } \\
\text { review. }\end{array}$ \\
\hline
\end{tabular}

The distinction between legality and legitimacy is significant both in theory and practice of law. Review of "legality" focuses rather on the legal underpinnings of a decision according to which judicial authority can attributed to a decision.

Table 6. Review of Legality

\begin{tabular}{|c|c|c|}
\hline $\begin{array}{l}\text { Review of } \\
\text { legality }\end{array}$ & $\begin{array}{l}\text { Intermediate Appellate } \\
\text { Review }\end{array}$ & $\begin{array}{l}\text { Higher } \\
\text { Appellate } \\
\text { Review }\end{array}$ \\
\hline $\begin{array}{c}\text { Review of } \\
\text { legality of } \\
\text { the decision }\end{array}$ & $\begin{array}{l}\text { Subsequent to a mere } \\
\text { examination of the file, the } \\
\text { court of appeal can decide } \\
\text { to have the proceedings } \\
\text { resume before a first } \\
\text { instance court in case one } \\
\text { of the following has } \\
\text { occurred: } \\
\text { - a judge who's proscribed } \\
\text { from hearing the case has } \\
\text { given the relevant decision } \\
\text { of the first instance court; } \\
\text { - a judge who has been } \\
\text { rightfully rejected was } \\
\text { sitting at the first instance } \\
\text { court; } \\
\text { - the first instance court's } \\
\text { has rejected to hear the } \\
\text { case for absence of } \\
\text { competence or jurisdiction } \\
\text { in an unjustifiable manner; } \\
\text { - the first instance court } \\
\text { has decided on the case } \\
\text { despite not having } \\
\text { competence } \\
\text { jurisdiction; } \\
\text { - nonobservance of other } \\
\text { general conditions sought } \\
\text { for judiciary action; } \\
\text { - undue nullification of } \\
\text { judiciary action; } \\
\text { - erroneous decision for } \\
\text { joinder or separation of } \\
\text { action; } \\
\text { - error at declaring } \\
\text { another court competent; } \\
\text { - the first instance court } \\
\text { has decided without } \\
\text { collecting any of the } \\
\text { declared evidentiary items } \\
\text { or without considering any } \\
\text { of the evidentiary items. }\end{array}$ & $\begin{array}{l}\text { Review on } \\
\text { conditions } \\
\text { of judiciary } \\
\text { action. }\end{array}$ \\
\hline
\end{tabular}




\begin{tabular}{|c|l|l|}
\hline $\begin{array}{c}\text { Condition } \\
\text { incumbent } \\
\text { on the } \\
\text { appellant }\end{array}$ & $\begin{array}{l}\text { If the relevant first } \\
\text { instance court is not within } \\
\text { the jurisdiction of the } \\
\text { court of appeal, } \\
\text { proceeding would resume } \\
\text { before a first instance } \\
\text { court. }^{46} \text {. }\end{array}$ \\
\hline
\end{tabular}

The subsequent stage of intermediate appellate review which constitutes of the review of legitimacy is rather concerned with conformity to norms of law whether procedural or substantive.

Table 7. The Subsequent Stage of Intermediate Appellate Review

\begin{tabular}{|c|c|c|}
\hline $\begin{array}{l}\text { Review of } \\
\text { legitimacy }\end{array}$ & $\begin{array}{l}\text { Intermediate } \\
\text { Appellate Review }\end{array}$ & $\begin{array}{l}\text { Higher Appellate } \\
\text { Review }\end{array}$ \\
\hline $\begin{array}{c}\text { Full } \\
\text { examination } \\
\text { of the file } \\
\text { without } \\
\text { hearing }\end{array}$ & $\begin{array}{l}\text { If as a result of a } \\
\text { full examination of } \\
\text { the file in respect } \\
\text { of its merits, the } \\
\text { court of appeal can } \\
\text { decide, } \\
\text {-to reject the } \\
\text { appeal in case of } \\
\text { conformity with all } \\
\text { applicable norms } \\
\text { of procedural and } \\
\text { substantive norms }\end{array}$ & $\begin{array}{l}\text { Subject to a } \\
\text { pecuniary } \\
\text { threshold } \\
\text { (applicable to the } \\
\text { applicant's } \\
\text { interest), a single } \\
\text { hearing may be } \\
\text { organised } \\
\text { generally upon the } \\
\text { demand of a party, } \\
\text { or exceptionally, } \\
\text { ex officio. }\end{array}$ \\
\hline
\end{tabular}

${ }^{46}$ As it is, the context where relevant clause of the Code of Civil Procedure, Article 353, alinea (a/3) is worded appears problematic. While other reasons for resumption of proceedings at a first instance court suggest illegality of the first instance court's decision, resumption, e.g. for an erroneous wording of the aimed court of appeal is conducive to a resut out of proportion. The legislator's intention could be pragmatic, simply to have the court of appeal return the file to the original first instance court for the issue to be dealt with by the author of the application rather than having the courts resolve the issue in an ex officio manner. Konuralp (2006) emphasized that the jurisdiction of each court of appeal is a matter of public order. (H. Konuralp, "Medeni Usul Hukuku", Anadolu University, 2006, p.181). Moreover, Kuru et alias (2008) asserted that an error in the indication of the competent regional court of appeal could be rectified by the first instance court. (B. Kuru, R. Arslan, E. Yılmaz, "Medeni Usul Hukuk", Yetkin Publication House, 2008, p. 643 f.)

\begin{tabular}{|c|c|c|}
\hline & $\begin{array}{l}\text { and rules; } \\
\text {-to rectify itself the } \\
\text { decision if, despite } \\
\text { an erroneous } \\
\text { application of the } \\
\text { law or an error } \\
\text { within the court's } \\
\text { rationale, it is not } \\
\text { necesssary to } \\
\text { resume the } \\
\text { proceedings; } \\
\text {-on the substance } \\
\text { of a case, after a } \\
\text { deficiency which } \\
\text { was detected is } \\
\text { made up for. }\end{array}$ & $\begin{array}{l}\text { The pecuniary } \\
\text { threshold is not } \\
\text { relevant if the } \\
\text { decision to review } \\
\text { concerns, } \\
\text {-dissolution of a } \\
\text { legal entity } \\
\text { (corporation); or } \\
\text {-rescission of a } \\
\text { general assembly } \\
\text { decision; } \\
\text {-the property of } \\
\text { real-estate. }\end{array}$ \\
\hline $\begin{array}{c}\text { Possibility } \\
\text { for a hearing } \\
\text { during } \\
\text { judicial } \\
\text { review } \\
\end{array}$ & $\begin{array}{l}\text { No pecuniary } \\
\text { threshold exists for } \\
\text { a hearing upon } \\
\text { demand. Single } \\
\text { hearing }\end{array}$ & \\
\hline $\begin{array}{l}\text { Other norms } \\
\text { of procedure }\end{array}$ & $\begin{array}{l}\text { The type of } \\
\text { procedure } \\
\text { applicable to the } \\
\text { first instance } \\
\text { would govern the } \\
\text { appellate } \\
\text { proceedings } \\
\text { without prejudice } \\
\text { to any other } \\
\text { provision included } \\
\text { in the related } \\
\text { section of the Code } \\
\text { of Civil Procedure }\end{array}$ & $\begin{array}{l}\text { The procedural } \\
\text { norms are specific } \\
\text { to higher appellate } \\
\text { review and } \\
\text { established in the } \\
\text { relevant section of } \\
\text { the } 2011 \text { Code of } \\
\text { Civil Procedure. }\end{array}$ \\
\hline
\end{tabular}

Overall, if the appeal succeeds the conditions of admissibility to intermediate appellate review, then at a next step, the points in focus concern the "legality" of the first instance court's decision. If the decision fails the legality test, it constitutes the reason for the proceedings to resume before a first instance court subsequent to obliteration of the reviewed decision. The reason why the points in focus at that stage evoke legality is because they relate to the underpinnings of the decision, e.g. the composition of the court and other major nonobservance of procedural norms. That being said, the second aspect of legality is more formal because it requires observance of the general conditions of judiciary action. According to the Code of Civil Procedure, Article 114, (general) conditions of judiciary action require, viz., jurisdiction of the courts of the Republic of Turkey, competence of the specific court, jurisdiction of the court if jurisdiction is attributed to a court in a mandatory manner, appropriateness of the type of judiciary forum, capacity to initiate action, representatives' due and sufficient power of representation, legal power to obtain the requested decision, payment of advance for costs, compliance with any ruling for deposit of caution, legitimate interest in initiating the judiciary action, being the first and single judiciary action on its subject- 
matter. $^{47}$ Failure from the first aspect of legality can rather be imputed to the specific court.

If the appeal fails the test of admissibility and if the failure cannot be restored, the right of appeal is exhausted. In case the decision fails the test of legality, the first instance court's decision is obliterated and proceedings are to resume before a court of first instance. If the proceedings resume before the same first instance court or even the proceedings start over at another first instance court, it cannot be said that the right of appeal is exhausted because a new first instance court is expected to render a new decision, but frequently between the same parties $r e$ the same cause. Finally, if the court of appeal examines the application as to review the merits of the first instance decision, the right of appeal is exhausted because the court of appeal is to resolve the subjectmatter. Therefore, it cannot be deduced that appeal automatically exhausts the right of appeal over the subject-matter.

Subsequently, the 2011 Code of Civil Procedure, Article 360 provides that the type of procedure applicable to the relevant first instance is to govern the intermediate appellate review; the type of procedure can be adopted by intermediate appellate review to the extent a norm specific to intermediate appellate review is not contrary to the applicable norm of such general procedure. ${ }^{48}$ The types of procedure established by the 2011 Code of Civil Procedure comprise of written procedure and simplified procedure which are essentially applicable to first instance proceedings. Therefore, their norms can be relevant to appellate review when there is no other procedural norm applicable to the intermediate appellate review; absent any procedural norm regulating the intermediate appellate review, the norm to apply during the intermediate appellate procedure is that of the procedure which (should) have governed its first instance proceedings. As such the same procedural norm as concerns the declaration of the final decision is to govern the declaration of the appellate decision; ${ }^{49}$ according to a flexible construction of the provision, the court of appeal can also decide for temporary protective measures during the appellate proceedings even more so since it is not among acts proscribed for intermediate appellate review. 50

In this vein, it is noteworthy that the 2011 Commercial Code provides for simplified procedure to govern various types of commercial law requests; such

${ }^{47}$ By law, the stated provision is without prejudice to specific provisions on conditions of judiciary action by other acts as applicable.

${ }^{48}$ Op. cit., Kuru et al., "Medeni Usul Hukuku", 2008, p. 654

49 i. Ercan, "Medeni Usul Hukuku", Themis Publication House, 2011, p. 387

${ }^{50}$ Op. cit, T. Akkaya, "Medeni Usul Hukukunda Istinafa Başvuru, istinaf incelemesi ve istinaf Mahkemesinin Verebileceği Kararlar”, p. $361 \mathrm{ff}$. occurs when it is explicitly stated that the "simplified procedure" would govern the relevant proceedings, or due to the reference of the 2011 Code of Civil Procedure, Article 316 alinea (b) and (g), when the court is conferred discretion to resolve an issue by examining the file and/or where the law provides for examination on file; if the legislator intends to put forth a way to proceed with the action, examination on file effectively becomes a procedure other than the (regular) written procedure provided by the 2011 Commercial Code in which case the "simplified procedure" is to govern the proceedings.

The same applies for proceedings on noncontentious commercial issues which are governed, according to the 2011 Code of Civil Procedure, Article 385 , para.1, by simplified procedure to the extent the nature of proceedings is compatible with simplified procedure. In principle, noncontentious issues are also subject to intermediate appellate review.

\section{TyPES OF APPEllate DeCisions}

Depending on the leads or aspects of the first instance court's decision which have been appealed, the intermediate appellate review can be favorable or unfavorable to the appeal:

\section{Table 8. Types of Appellate Decisions}

\begin{tabular}{|c|c|c|}
\hline $\begin{array}{l}\text { Results of } \\
\text { review }\end{array}$ & $\begin{array}{c}\text { Intermediate } \\
\text { Appellate Review }\end{array}$ & $\begin{array}{c}\text { Higher Appellate } \\
\text { Review }\end{array}$ \\
\hline $\begin{array}{c}\text { Types of } \\
\text { appellate } \\
\text { decisions } \\
\text { favorable to } \\
\text { the appeal }\end{array}$ & $\begin{array}{l}\text { - Appellate decision } \\
\text { for resumption of the } \\
\text { lawsuit for } \\
\text { nonobservance in } \\
\text { respect of conditions } \\
\text { of legality; } \\
\text { - Appellate decision } \\
\text { favorable to a point } \\
\text { of appeal after } \\
\text { rectifying the } \\
\text { decision if, despite } \\
\text { an erroneous } \\
\text { application of the } \\
\text { law or an error } \\
\text { within the court's } \\
\text { rationale, it is not } \\
\text { necesssary to resume } \\
\text { the proceedings; } \\
\text { - Appellate decision } \\
\text { partially or } \\
\text { completely accepting } \\
\text { the request(s) of an } \\
\text { appellant, } \\
\text { subsequent to a full- } \\
\text { scale appellate } \\
\text { review. }\end{array}$ & $\begin{array}{l}\text { Appellate decision } \\
\text { quashing the first } \\
\text { instance court's } \\
\text { decision partially or } \\
\text { entirely in case of an } \\
\text { erroneous application } \\
\text { of the law or the } \\
\text { contract between the } \\
\text { parties, or } \\
\text { nonobservance of a } \\
\text { condition for judiciary } \\
\text { action. }\end{array}$ \\
\hline $\begin{array}{c}\text { Types of } \\
\text { appellate } \\
\text { decisions } \\
\text { unfavorable } \\
\text { to an appeal }\end{array}$ & $\begin{array}{l}\text { - Appellate decision } \\
\text { rejecting the appeal } \\
\text { for inadmissibility of } \\
\text { appeal; } \\
\text {-Appellate decision } \\
\text { partially or } \\
\text { completely rejecting } \\
\text { the requests of an } \\
\text { appellant party; }\end{array}$ & $\begin{array}{l}\text { - Approval of the first } \\
\text { instance court's } \\
\text { decision when the } \\
\text { first instance court's } \\
\text { decision is in } \\
\text { conformity with } \\
\text { norms of procedural } \\
\text { law as well as } \\
\text { substantive law; } \\
\text { - Approval of the first }\end{array}$ \\
\hline
\end{tabular}




\begin{tabular}{|l|l|l|}
\hline & $\begin{array}{l}\text { instance court's } \\
\text { decision after } \\
\text { rectifying an } \\
\text { erroneous point in the } \\
\text { court's rationale, } \\
\text { identification of a } \\
\text { party, wording, } \\
\text { calculation or a } \\
\text { phrasing contained in } \\
\text { the decision if it is not } \\
\text { necessary to have the } \\
\text { proceedings resume } \\
\text { for such error; } \\
\text { Decision rejecting } \\
\text { the appeal for } \\
\text { nonobservance of a } \\
\text { rule of admissibility } \\
\text { for higher appellate } \\
\text { review. }\end{array}$ \\
\hline
\end{tabular}

\section{REFERENCES}

A.C. Budak (2011) "Hukuk Muhakemeleri Kanunu'nun Getirdiği Başlıca Yenilikler", Conference held at Bakırköy Center of the Istanbul Bar Association on 14 May 2011, published by the Istanbul Bar Association: B. Kuru, A.C. Budak, "Hukuk Muhakemeleri Kanunu'nun Getirdiği Başlica Yenilikler" in Istanbul Barosu Dergisi, Vol. 85, no.5, 2011, available at www.istanbulbarosu.org.tr

B. Kuru, R. Arslan, E. Yilmaz, "Medeni Usul Hukuk", Yetkin Publication House, 2008

"Bölge Adliye Mahkemelerinin Kurulmasına İlişkin Karar", Resmi Gazete (Official Gazette) of 5 June 2007, no 26543, and see also Act no. 5235 "Adlî Yarg1 İlk Derece Mahkemeleri ile Bölge Adliye Mahkemelerinin Kuruluş, Görev ve Yetkileri Hakkında Kanun", Resmi Gazete (Official Gazette) of 7 October 2004, no. 25606.

C. Akil, "İstinaf Kavramı", University of Ankara, 2008, $\mathrm{PhD}$ thesis available at www.yok.gov.tr

C. A. Celik, "Tazminat ve Alacak Davaları", Bilge Yayınevi, Ankara, 2012

European Commission for the Efficiency of Justice (CEPEJ) of the Council of Europe, reports entitled "Evaluation Report on European Judicial Systems", Council of Europe, available at www.coe.int .

H. Konuralp, "Medeni Usul Hukuku”, Anadolu University, 2006

İ. Elveriş, G. Jahic, S. Kalem, "İstanbul Asliye Hukuk Mahkemelerinde Yargilama Süreci”, İstanbul Bilgi University Publications, 2009

İ. Ercan, "Medeni Usul Hukuku", Themis Publication House, 2011
J. Héron, T. Le Bars, "Droit judiciare privé", Montchrestien, 2011

Ö. Ulukap1, Regulation of Co-action under the Law of Civil Procedure", University of Ankara, 1990, Thesis available at www.yok.gov.tr

P. Gottwald, " Comparative Civil Procedure" in Ritsumeikan Law Review", 2005/3, No. 22, p.25; translation republished as "Karşılaştırmalı Medeni Usul", in "Prof. Dr. Saim Üstündağ'a Armağan" Adalet Publication House, 2009

TBMM Tutanak Dergisi (Review of the minutes of the Turkish Parliament's sessions), Dönem 22, 5. Sayıs1, 152, Yasama Y1l1 1, p. 11, cited by M. A. Tutumlu, "Medeni Yargılama Hukukunda Delillerin İleri Sürülmesi”, 2007 